\title{
The Liturgical Reform of Vatican II: The Philippine Experience
}

\author{
Anscar J. Chupungco
}

\section{ABSTRACT}

The current reform of the liturgy undertaken by a movement known as the "reform of the reform" carries an agenda that can have an impact on the liturgical gains of the Second Vatican Council in the Philippines. The agenda attempts to retrieve discarded liturgical practices and paraphernalia, but this sometimes results in the loss of active participation. Proponents of this counter-reform movement refer to it as a "hermeneutic of continuity" with the Church's tradition of worship. The paper argues that these counterreforming attempts actually overlook the fact that the Church has been acknowledging and responding to changes in social and religious culture.

KEYWORDS: Liturgical theology, reform of liturgy

\section{The Hermeneutic of Continuity}

Dark clouds are forming ominously on the western horizon. They move hurriedly and decisively toward the direction of the sun that burns radiantly in the sky. They cast upon it their somber shadows to hide it from view. Suddenly it is dusk before the appointed time. In reality however the dimness is caused by the passing clouds. These cannot rewind the clock to yesterday's evening hours.

This is how I would describe the state of liturgical reform some fifty years after the Second Vatican Council (or Vatican II). The reform is being put to task by a movement known as the "reform of the reform" or in a word, counter-reform. It carries an agenda that can have in the Philippines a regrettable impact on the liturgical gains of the council. The agenda is an attempt to retrieve dis- 
Anscar J. Chupungco, "The Liturgical Reform of Vatican II: The Philippine Experience"

carded liturgical practices and paraphernalia that sometimes results in the loss of active participation. It conveniently forgets that half a century before Vatican II, the Church had already begun marching with the times, acknowledging the changes in social and religious culture, and adopting new pastoral strategies. Proponents of this counter-reform movement refer to it as a "hermeneutic of continuity" with the Church's tradition of worship. By tradition they mean the Tridentine rites, which the Church had jealously safeguarded for four hundred years. My name for the movement is "romantic historicism."

Based on my readings, it is plain that the proponents of the "reform of the reform" expediently anchor themselves on the liturgical musings of theologian Joseph Ratzinger. After his election to the papacy his thinking on the conciliar reform that Pope Paul VI had set in motion gained the status of a Magna Carta.

I draw some of Ratzinger's striking and somewhat stifling utterances on Vatican II's liturgical reform from his two books, The Feast of Faith and The Spirit of the Liturgy. I find it telling that both were published by the Ignatius Press. Ratzinger dismisses the new liturgy as the "the product of erudite work" of liturgical scholars imposed on the whole Church by the "juridical authority" of Pope Paul VI. He regards the ban on the Missal of Pius V as "a breach into the history of the liturgy whose consequences could only be tragic." He distrusts the usefulness of the offertory procession and the sign of peace, which disrupt the preparation of the faithful for Holy Communion. He suggests (and I personally heard this) that on certain occasions the Eucharistic Prayer or at least the words of institution be recited silently. As a compromise, the priest may recite aloud the first line of each section of the Eucharistic Prayer so that the faithful could follow with their missals. Furthermore the posture of priests as leaders of worship is enhanced when they do not face the community, which has created the impression of a "self-enclosed circle" not open to what is ahead and above. He also grieves the disappearance of Europe's treasury of liturgical music in favor of local compositions.

Under the aegis of Ratzinger's authority the proponents of the "hermeneutic of continuity" have all the backing they need to propagate the reform of the reform. When Pope Benedict XVI was asked how he planned to pursue the agenda, he replied that the force of example is a more prudent option than a papal decree, which could be divisive. And yet to the chagrin of a large sector 
of Catholics, he published Summorum Pontificum in 2007 permitting the widest possible use of the Tridentine liturgy as forma extraordinaria of the Roman rite. Pope Benedict XVI restored to life a medieval rite whose death Joseph Ratzinger had mourned.

The "hermeneutic of continuity" has thus a double agenda. Papal juridical authority, to use the expression of Ratzinger, restored the Tridentine liturgy, although such would appear to be at odds with Article 50 of the Constitution on the Sacred Liturgy. But who am I to question sovereign prerogative? The second item on the agenda is the gradual correction of the post-conciliar reform of the liturgy. The papal master of ceremonies, Msgr. Guido Marini, made the startling announcement in January 2010 that there is a need to reform the reformed liturgy. He intimated that the post-conciliar experts (several of them were my mentors) did not grasp fully the meaning and intention of the constitution of the liturgy, which they had drafted and presented to the council fathers. He claimed that as a result, post-conciliar reform has "not always in its practical implementation found a timely and happy fulfilment."

This disquieting movement has landed upon Philippine shores. Its local advocates invoke papal authority as they witch-hunt those that manifest reticence toward the use of the defunct Latin language and the singing of doleful chants from distant generations. It is no longer a requirement to understand what is said, sung, or read. The advocates of counter-reform argue that for four hundred years the faithful did not understand the words of the liturgy: they simply went to Mass and many of them became saints! In the end what matters, we are told, is that worship should be shrouded in the atmosphere of the mysterium tremendum et fascinans amidst thick clouds of incense and lighted candles. This is not only romantic historicism; it is also the perfect lack of pastoral sense.

Dark clouds are forming ominously on the western horizon. They move hurriedly and decisively toward the direction of the sun that burns radiantly in the sky. They cast upon it their somber shadows to hide it from view. Suddenly it is dusk before the appointed time. In reality however the dimness is caused by the passing clouds. These cannot rewind the clock to yesterday's evening hours. 
Anscar J. Chupungco, "The Liturgical Reform of Vatican II: The Philippine Experience"

\section{Continuity with the Classical Roman Tradition}

Tiny white flowers carpet the green grass. Up in the northern hemisphere, the darkness and storms of winter finally give way to fresh and brighter mornings: "sweet the rain's new fall, sunlit from heaven, like the first dewfall on the first grass." Nature burgeons with new life, grace, and charm. It is springtime! Fifty years ago it was also the springtime of liturgy.

When the schema on the liturgy was presented to the council, it was ripe for discussion. It did not appear out of the blue. In 1909 Dom Lambert Beauduin, a Benedictine monk of the Abbey of Mont-César, delivered a speech at the Workers' Congress in Malines, Belgium. In the face of the crisis of religious indifference and the threats of emerging political and economic systems in Europe, he proposed the full and active participation of the faithful in the life of the Church, especially in the liturgy, as the effective response to the perils that were besetting society. According to him, the root of religious indifference was the ignorance of the liturgy. Beauduin was a soft-spoken and unassuming monk, but when he spoke the world listened.

His speech was like a wake-up call that roused pastors and scholars to open their eyes to the power of the liturgy. Thus the movement started. It was a movement that aimed to infuse vitality to the liturgy, which for several centuries could be likened to a still-life portrait. It gained support in monasteries and spread like wildfire across Europe and the other continents.

In 1947 Pope Pius XII issued Mediator Dei, a historic encyclical dealing exclusively with the liturgy. Although the encyclical cautioned against the abuses that were being committed by over-zealous proponents of liturgical change, it officially recognized the liturgical movement and inaugurated a series of liturgical changes that would lead to the Second Vatican Council. For example, in that same year Belgium received permission for the celebration of evening Mass on Sundays and holy days; in 1949 the translation of the Roman Missal (except for the Roman Canon) into the Mandarin language was approved by the Holy See; and in 1956 the rites for the Holy Week were revised. These were truly gigantic strides for the time. At the conclusion of the international liturgical congress held in Assisi in 1956, the 1,400 participants travelled to Rome to listen to the address of Pope Pius XII. The Pope affirmed that the liturgical movement was "a sign of God's providence and of the movement of 
the Holy Spirit in the Church, bringing people closer to the mystery of faith and the grace that comes through liturgical participation."

The movement had a weighty influence on the shaping of the Constitution on the Sacred Liturgy of Vatican II. It bears the name "classical," because it favored a reform that took as model the classical shape of the liturgy that existed in Rome from the fifth to the eighth century. This classical form was distinguished by the Roman cultural genius that consisted of sobriety (the celebrated sobrietas romana and sobria ebrietas), brevity and simplicity, and practical sense. Proponents of the movement opted for this type of liturgy as effective means of fostering the full, active, and conscious participation of the faithful. Complicated and repetitious liturgical rites, which encumbered the medieval Tridentine rites, did not facilitate the understanding of divine worship. They deterred intelligent and active participation, which was the movement's primary concern.

My study of the acts of the council rewarded me with a noteworthy discovery. When the schema of the Constitution was read to the fathers, several bishops especially from the missions took exception with the proposed retrieval of the classical form. For them it looked hopelessly archeological, obsolete, and not consonant with the pastoral intent of Pope John XXIII. The reply of the conciliar commission is enlightening. When the classical Roman liturgy migrated to the German territories in the eighth century, it absorbed medieval traits that the German popes transported in turn to Rome in the tenth century. Furthermore (and this comforted the missionary bishops) the classical shape of the Roman liturgy, because of its simplicity and clarity, proved to be more easily adaptable to local Churches across the globe. This was shown by the successful adaptation of Rome's classical liturgy to the German culture in the eighth century. The sixteenth-century Tridentine rites codified this German version of the Roman liturgy.

On December 4, 1963 the 2,152 council fathers voted on the constitution with a solid 2,147 votes in favor. Thereupon Pope Paul VI gave his approval and promulgation of the first conciliar constitution. The Pope, in his address at the conclusion of the second session of the council, declared: "The arduous and intricate discussions have certainly borne fruit, for one of the topics-the first to be discussed and, in a certain sense, the first in order of intrinsic excellence and importance for the life of the Church, the schema on the sacred liturgy-has been brought to a happy conclusion." 
Anscar J. Chupungco, "The Liturgical Reform of Vatican II: The Philippine Experience"

How did the classical liturgical movement influence the constitution of the liturgy? If we check the names of those who formed the commission that drafted the constitution, we have a ready reply. Lest these giants of liturgical reform fade from our collective memory, allow me to name them: Annibale Bugnini (secretary), Karel Calewaert, Bernard Capelle, Enrico Cattaneo, Romano Guardini, Josef Jungmann, Joseph Malula, Johannes Quasten, Mario Righetti, Aimon-Marie Roguet, Bernard Botte, Antoine Chavasse, Godfrey Diekmann, Balthasar Fischer, Pierre-Marie Gy, Anton Hänggi, Johannes Hoffinger, Pierre Jounel, Theodor Klauser, Boniface Luykx, Frederick McManus, Aimé-Georges Martimort, Herman Schmidt, Cipriano Vagaggini, and Johannes Wagner. These were pastors and scholars that supported the classical liturgical movement and lent credibility and seriousness to it. Because of them the principles of the fifty-year old classical reform entered the council hall. I had the unique privilege of sitting at their feet with humility and awe.

Tiny white flowers carpet the green grass. Up in the northern hemisphere, the darkness and storms of winter finally give way to fresh and brighter mornings: "sweet the rain's new fall, sunlit from heaven, like the first dewfall on the first grass." Nature burgeons with new life, grace, and charm. It is springtime! Fifty years ago it was also the springtime of liturgy.

But the springtime of liturgy quickly retreated when Pope Paul VI began to implement the conciliar provisions, especially those regarding the Roman Missal. Two extreme, and I should say unhealthy, reactions marred post-conciliar reform. Carried away by reckless euphoria, some individuals engaged in censurable experimentations, such as the creation of personal Eucharistic Prayers. The Congregation for Divine Worship swiftly responded to this by issuing in 1970 the Third Instruction Liturgicae instaurationes to correct abusive practices. Since then, this Vatican Congregation has been behaving like a watchdog ready to show its teeth. In March 25, 2004 it published the instruction on the Eucharist entitled Redemptionis sacramentum. Leafing through the pages, I discovered that the instruction is virtually a roll call of Eucharistic do's and don'ts. Several don'ts are categorized as "delicts."

Disenchantment and outright opposition met the post-conciliar reform. No less than Cardinals Alfredo Ottaviani and Antonio Bacci endorsed opposition to the new missal for its "heretical," "psychologically destructive," and "Protestant" elements. A French cleric even called for the deposition of Pope 
Paul VI whom he accused of heresy, schism, and scandal. These were indeed unflattering reactions to the springtime of liturgy.

But the unrelenting and assiduous opposition came from Archbishop Marcel Lefèbvre. It came like a bolt from the blue, because the archbishop had been a council father. He affirmed that the Vatican had embraced "neoModernism" and "neo-Protestantism" during and after the council, especially in the revised missal. In his letter to Lefèbvre on October 11, 1976 Pope Paul VI did not mince his words: "As for you, the former rite of Mass is a sign of your false ecclesiology and a matter on which to assail the Council and its work of reform. You take as a pretext or as your alleged justification that only in the former rite are the authentic sacrifice of the Mass and the authentic ministerial priesthood preserved, their meaning unobscured. We reject out-of-hand this erroneous judgment and unjust accusation; we cannot permit the divine Eucharist, sacrament of unity, to be made the source of division (see 1 Cor 11:18); we cannot permit you to make use of it as an instrument and symbol of your rebellion."

The pope could rightly claim that the post-conciliar reform was carefully implemented in accord with the charter of the Constitution on the Sacred Liturgy. An interplay between tradition and progress permeated this conciliar document. Article 23 is significant: "That sound tradition may be retained and yet the way remain open to legitimate progress, a careful investigation is always to be made into each part of the liturgy to be revised." At the time of the council the Church was in a period of transition from Trent to modern age. The framers and implementers of the constitution were not of the mind to undercut Trent. They wanted to address the new developments in the Church by a new methodology grafted on pastoral care and scholarly research. The expression "sound tradition and legitimate progress" is the hallmark of Vatican II's liturgical reform.

Some time ago Fr. Anthony Cekada who was ordained priest by Lefèbvre requested me to write a review of his book Work of Human Hands: A Theological Critique of the Mass of Paul VI. As a traditionalist he finds it extremely ironic that his conclusion about theological shift from Trent to Vatican II is a lot closer to scholars on my side of the spectrum than it is to the conservatives who hold the "continuity" position. I am flabbergasted. I beg to differ with him on his claim that there is "theological discontinuity." The Missal of Paul VI is not a departure from Tridentine theology but a balanced approach to the character 
Anscar J. Chupungco, "The Liturgical Reform of Vatican II: The Philippine Experience"

of the Mass as both sacrifice of the cross and supper of the Lord. However, I do agree that there is a certain discontinuity in liturgical rites, rubrics if you wish, because the Missal of Paul VI opted for the classical Roman liturgy as its principal model.

Since the Missal of Paul VI is the target of a wave of antagonism (alas, it has entered the Philippine shore), allow me to explain the grounds for revising the missal.

Article 50 of the Constitution on the Sacred Liturgy directs that "the Order of Mass is to be revised in a way that will bring out more clearly the intrinsic nature and purpose of its several parts, as also the connection between them, and will more readily achieve the devout, active participation of the faithful." To achieve this, the constitution desires that rites be simplified, duplications or additions with little advantage be discarded, and traditional elements that have fallen into disuse be restored in the tradition of the Fathers, if they seem useful or necessary. All this implies not a mere fine-tuning of the Tridentine Missal but a radical revision involving notable changes in structure, prayer texts, scriptural readings, and rubrics. In 1968 Pope Paul VI promulgated three new Eucharistic Prayers, and he followed these with the Eucharistic Prayers for Children and for Reconciliation in 1974. He broke the millenary tradition of using only the Roman Canon for Mass. I am certain that Pope Pius V will not recognize his missal in the new version, as the supporters of the "hermeneutic of continuity" likewise will not.

In the thinking of Joseph Ratzinger, "the new Missal was published as if it were a book put together by professors, not a phase in a continual growth process." In his view, a new edition of the post-conciliar Missal will have to make it clear "that the so-called Missal of Paul VI is nothing other than a renewed form of the same Missal to which Pius X, Urban VIII, Pius V and their predecessors have contributed, right from the Church's earliest history." We arrive then at the heart of the "hermeneutic of continuity." My hunch is that the liturgical history of theologian Ratzinger does not cover the classical period of the Roman liturgy that disappeared in the tenth century when the Germans fiddled with it in order to satisfy the demands of their socio-religious culture. By the way, I apologize to him for my persistent use of terms like "Tridentine liturgy," "Missal of Pius V," "Vatican II liturgy," and "Missal of Paul VI." He 
claims that such nomenclature undermines the "unbroken continuity" of the liturgy throughout the history of faith.

\section{The Philippine Hermeneutic of Progressive Tradition}

Bougainville and hibiscus flowers blossom in the heat. Ripe fruits array the branches of trees. Children frolic in defiance of the scorching sun. There will be no more violent storms and vicious floods. It's summertime! The Church in the Philippines is joyfully and gratefully harvesting the fruits of Vatican II.

The political turmoil in the $19^{\text {th }}$ century and the social discontent under the Spanish rulers and friars did not cause the Filipinos to abandon the Catholic faith and the religious practices they had inherited from Spain. However, in the spirit of nationalism a Church independent from Rome was proclaimed in 1902. It was this Church that pioneered the celebration of the liturgy in the vernacular. The arrival of American Protestants, many of whom were school teachers, helped to set the stage for Filipino Catholics to welcome the use of the vernacular in the Mass. In the $19^{\text {th }}$ century the Catholic faithful, despite the ferment of revolution against Spain, continued to attend Sunday Mass in traditional Latin and to celebrate the feasts of the towns' patron saints.

The Mass was celebrated in the style of the baroque period, with choir and orchestra on special feasts and the ringing of church bells at the consecration. Holy Communion by the faithful was infrequent. The focus of the celebration was the elevation, when the church bells were rung, the Spanish anthem was played outside the church, and firecrackers sounded to greet the Eucharistic King. It was a tradition that dated from the $16^{\text {th }}$ century that the sermon was in the vernacular because it was for the instruction of the faithful. Until the reform of Vatican II it had been commonly observed that men stepped out of the church during the sermon. Since the Mass was in Latin and there was no way to actively take part in it, women silently recited the rosary. Pictures of veiled women with the rosary in their hands depict the situation of this period. It was proverbial that some men entered the church only three times in their lifetime: at their own baptism, marriage, and funeral. The Roman Catholic Church in the Philippines was caricatured as the church of women and children. 
Anscar J. Chupungco, "The Liturgical Reform of Vatican II: The Philippine Experience"

This is a thumb-nail sketch of the liturgical life in the country when European and American missionaries brought in the liturgical movement. By the late 1950's tentative translations of liturgical prayers and readings for use of the faithful existed in some vernacular languages. But active participation and lay liturgical ministry did not come about until after the conciliar reform. The majority of Filipino Catholics accepted the changes coming from Rome, even if a great deal of coaching was needed to wean them from devotional practices during Mass. The people welcomed the shift to the vernacular, they became used to seeing the priest face the people, and they sang without difficulty the Ordinary of the reformed Mass.

I can name, among others, two factors that made a solid contribution to the liturgical renewal in the country. The first was the nation-wide dissemination of information regarding the reformed liturgy. This consisted of liturgy seminars for the clergy, the religious, and the lay leaders, as well as the use of mass media, especially the radio. Bishop William Brasseur, Fr. Camilo Marivoet, Fr. Hermann Gräf, and Fr. James Meehan must be credited for their espousal of the liturgical reform. The second factor was the influential Catholic movement called Cursillos de Cristiandad. This program of spiritual renewal for lay people filled the churches on Sundays and restored interest in the Mass. For the first time men volunteered as Mass servers, commentators, and readers.

The period immediately following the council saw the emergence of experimental Masses especially in schools, religious houses, and seminaries. It was claimed that in these places exception to the liturgical rule was the rule. Parishes, however, stuck pretty much to the published norms. In the 1970's there had been cases when unofficial texts and non-Biblical readings were used during Mass. Sometimes popular songs with no connection to the liturgy were sung as entrance, offertory, and communion songs. This situation improved thanks to the pioneering work of Fr. Eduardo Hontiveros who popularized songs based on Filipino colonial music. In the late 1960's and early 1970's some "inculturated" priests had the tenacity to use native food and drink, claiming that bread and wine are of foreign origin. Some others dispensed with the required vestments. During the same decade, especially under the rule of martial law, student Masses tended to be politically oriented: anti-government slogans, gestures, and banners decked the sacred rite. Things began to settle down in the 1980's after intense catechesis on the meaning of the Mass and reminders about how its celebration should be performed. 
In 1990 the conference of bishops issued the Guidelines for the Eucharist. The text explains the official norms for the celebration of Mass, provides information about the local adaptations approved by the conference of bishops regarding the use of local materials for the altar, vessels, and vestments, and suggests adaptations within the bounds of the Roman norms. In 1999 the conference approved the Philippine Supplement to the Roman Sacramentary containing the particular liturgical calendar and Masses for the country. As a sign of inculturation the conference endorsed in 1975 the Misa ng Bayang Pilipino, which is gathering dust in the Vatican archives, and in 1985 the Pagdiriwang ng Pag-iisang Dibdib, which miraculously received official nod.

A remarkable impact of the conciliar reform is the participation of lay leaders in the liturgical ministry. Large parishes have them by the hundreds. The Archdiocese of Manila is blessed with 12,000 lay ministers that act as readers, servers, commentators, and special ministers of communion. All in all, it can be affirmed that the liturgical renewal initiated by the council has taken deep roots among Filipino Catholics. The Church in the Philippines is harvesting the fruits of summer.

But we need to plant more trees. I hold that it is not enough to implement but also to be creative within the bounds of law. We will not be loyal to the council, if we bury the coin in the ground for fear of losing it and of facing an irate master. I believe in progressive liturgical tradition, that is to say, legitimate progress grafted on sound tradition. It is a process to which I give the name organic progression.

How do I define organic progression? It is the work of supplementing and completing, when necessary, the shape of the official liturgical books. I call it progressive because it develops the liturgical Ordo by supplementing what is lacking in it or completing what the reform has begun. I call it organic because the new liturgical rite it produces is coherent with the basic intention of the conciliar reform. Organic progression is not a novelty. It has been around since the time of the early Church Fathers.

Organic progression will keep the clock of liturgical reform ticking. But that is not how conservatives view things. In his speech at the $11^{\text {th }}$ International Colloquium for the Centre International d'Etudes Liturgiques (CIEL, or International Centre for Liturgical Studies) held in Oxford in September 2006 Alcuin Reid named me as the principal exponent of this "alarming prin- 
Anscar J. Chupungco, "The Liturgical Reform of Vatican II: The Philippine Experience"

ciple of liturgical reform." Dutifully echoing Ratzinger, he quipped that the Constitution on the Sacred Liturgy "did not intend to provide employment to generations of liturgists engaged in reconstructing the liturgy according to the desires of passing generations." I beg to differ with him. The history of the liturgy before the Council of Trent and after Vatican II bears witness to an ongoing process of inculturation through organic progression. I did not start it. In fairness to him, however, I should mention that he recently invited me to write two articles for his upcoming volume TET Clark Companion to Liturgical Studies.

Besides the introduction of new Eucharistic Prayers, here are a few other examples of organic progression. In 1972 Pope Paul VI reformed the "minor orders" reducing them to two (lector and acolyte), which were henceforth called "ministries" to distinguish them from the clerical orders. In the same year he instituted the form of general absolution. Beyond the explicit provision of the council he allowed the use of another kind of plant oil besides olive oil, and reintroduced the practice of repeating the anointing during the same illness if the person's condition worsens. What is remarkable about the last example is that the council had voted to delete the article regarding the repetition of anointing. Its resumption reveals the compassionate heart of Pope Paul VI.

By the method of organic progression the post-conciliar reform supplemented and filled in the lacunae of the conciliar constitution. If not for this courageous act that was visionary and progressive the Church today would have been sadly deprived of a richer liturgical life. That Pope Paul VI crossed beyond the letter of the Constitution on the Sacred Liturgy, though within its spirit and the parameters of liturgical tradition, is a sure sign of a trustworthy stewardship that knows not only how to preserve but also how to develop what is already there.

We can justly take pride in the success of the liturgical reform in the Philippines. It seems to me however that long-term success should go along with the hermeneutic of progressive tradition. Time constraint does not allow me to dwell at length on the areas that are open to organic progression. I will simply enumerate some of them.

One of the acid criticisms of conservatives and traditionalists of the new way of celebrating the Mass is its seeming absence or diminution of sacral setting. The Mass, it is observed, has oftentimes the semblance of a convivium where entertainment precedes worship. Perhaps liturgical reform has come to 
that stage of development when awareness of the divine, of Christ's sacrifice, and of his Last Supper are once again recovered, so that amidst ritual activities the worshipers stand in awe at the presence of the mystery. In a word, the hermeneutic of progressive tradition reminds us that liturgy is above all an encounter with the divine. It is prayer, not entertainment. It is an assembly of worshipers, not a social gathering.

The empowerment of women is rightly being promoted in many parts of the world. The Philippines is blessed with women, sometimes called "the women of Jerusalem," who dedicate their time and resources to the Church. However, they are officially at the periphery of the altar. Perhaps the time has come to invite them to come up higher and assume the role of altar servers. I realize that the reluctance of bishops stems from the observation that a good number of altar boys enter the seminary.

The council fathers consumed several hours debating on the use of the vernacular languages in the liturgy. It had not been easy to lay aside sacral Latin in favor of the vernacular, but good pastoral sense prevailed. Full, active, and intelligent participation, which is the charter of the Constitution on the Sacred Liturgy, requires ample understanding of what is heard and said.

The principal liturgical rites have been translated into the Philippine local languages. There is, however, a need for further refinement, not according to Cardinal Francis Arinze's ill-advised Liturgiam authenticam of 2001, which enjoins formal correspondence and junks dynamic equivalence, but according to the ill-fated 1969 Instruction on the Translation of Liturgical Texts. Furthermore, the hermeneutic of progressive tradition and pastoral sense warn us against the overuse of Latin at the expense of active participation.

I believe that inculturation is foremost among the areas that suffer the brunt of counter-reform. And this is happening a few years after the publication in 1994 of the Instruction: The Roman Liturgy and Inculturation. The council fathers must have perceived that liturgical inculturationis of such consequence to the renewal of worship in local Churches that they approved four relatively long articles on the subject.

Liturgical inculturation has lately been silenced because of the emerging desire of some sectors to reinstate medieval traditions represented by the 
Anscar J. Chupungco, "The Liturgical Reform of Vatican II: The Philippine Experience"

Tridentine liturgy. Yet I am of the persuasion that loyalty to Vatican II and pastoral care requires us to pursue the inculturation of liturgical rites, texts, symbols, and music.

There are surely many other areas where progressive tradition can bring the liturgical reform of Vatican II to fuller fruition. I can think of popular religiosity, environmental concerns, technology, socio-political issues, and endemic poverty in urban centers as well as far-flung provinces. However, we have every reason to thank the council fathers for their gift of liturgical renewal.

Bougainville and hibiscus flowers blossom in the heat. Ripe fruits array the branches of trees. Children frolic in defiance of the scorching sun. There will be no more violent storms and vicious floods. It's summertime! The Church in the Philippines is joyfully and gratefully harvesting the fruits of Vatican II.

That in all things God may be glorified.

\section{Works Consulted}

Botte, Bernard. From Silence to Participation: An Insider's View of Liturgical Renewal. Washington, D.C.: Pastoral Press,1988. Print.

Bugnini, Annibale. The Reform of the Liturgy: 1948-1975. Collegeville, Minn.: Liturgical Press, 1990. Print.

Chupungco, Anscar. What, Then, is Liturgy? Musings and Memoir. Collegeville, Minn: Liturgical Press, 2010. Print.

Marini, Piero. A Challenging Reform: Realizing the Vision of the Liturgical Renewal 1963-1975.

Ed. Mark R. Francis and Keith L. Pecklers. Collegeville, Minn.: Liturgical Press, 2007. Print.

Pecklers, Keith F. The Genius of the Roman Rite: On the Reception and Implementation of the New Missal. Collegeville, Minn.: Liturgical Press, 2010. Print.

Ratzinger, Joseph. The Feast of Faith: Approaches to a Theology of the Liturgy. Trans. Graham Harrison.San Francisco: Ignatius Press, 1986. Print.

---. The Spirit of the Liturgy.Trans. John Saward. San Francisco: Ignatius Press, 2000. Print.

Reid, Alcuin. "Sacrosanctum Concilium and the Organic Development of the Liturgy."The Genius of the Roman Rite: Historical, Theological, and Pastoral Perspectives on Catholic Liturgy. Ed. Uwe Michael Lang. Chicago: Hillenbrand, 2010. Print. 
Asian Perspectives in the Arts and Humanities 1:2 (2011): 79-93

Schema Constitutionis de Sacra Liturgia, Emendationes a Patribus conciliaribus postulatae and Modi a Patribus conciliaribus propositi. Vatican City: Typis Polyglottis Vaticanis, 1963. Print.

Schmidt, Herman. La costituzione sulla sacra liturgia: Testo, genesi, commento, documentazione. Rome: Herder, 1966. Print.

The Roman Liturgy and Inculturation: IVth Instruction for the Right Application of the Conciliar Constitution on the Liturgy. Rome: Vatican Press, 1994. Print.

Anscar J. Chupungco was a professor in and president of the Pontifical Liturgical Institute, and was rector magnificus of the Pontifical Athenaeum Anselmianum in Rome. He is presently the director of the Paul VI Liturgical Institute in Malaybalay, Bukidnon, and Secretary of the National Liturgical Commission of the CBCP. 